\title{
MENINGKATKAN MINAT DAN BUDAYA MEMBACA DENGAN MERINTIS RUMAH BACA MASYARAKAT DI GANG H. HASAN KOTA PONTIANAK
}

\author{
Eviliyanto $^{1}$, Rika Anggela ${ }^{2}$ \\ 1,2Program Studi Pendidikan Geografi Fakultas Ilmu Pendidikan dan Pengetahuan \\ Sosial IKIP PGRI Pontianak, Jalan Ampera Nomor 88 Pontianak \\ 1e_mail :Eviliyanto@yahoo.co.id
}

\begin{abstract}
Abstrak
Tujuan dalam pengabdian masyarakat ini adalah ingin meningkatkan minat dan budaya membaca dengan merintis rumah belajar masyarakat di Gang H. Hasan Kota Pontianak. Metode yang digunakan dalam pengabdian ini adalah survei lapangan dan Tinakan. Survey lapangan dilakukan dengan mendatangi lokasi, berkoordinasi dengan pihak warga yang akan ikut terlibat dengan kegiatan merintis rumah baca. Tindakan yang dilakukan adalah pengadaan alat dan bahan untuk membuat sarana untuk mendukung rumah baca dan pelaksanaan program.kegiatan yang telah dilaksanakan dalam merintis Rumah Baca Masyarakat di Gang H. Hasan kota Pontianak dapat dilihat bahwa pelaksanaan telah sesuai dengan indikator yang ingin dicapai. Terlihat dari fasilitas - fasilitas yang terkait untuk menjadi sarana dan prasarana di rumah baca dapat terpenuhi berupa lemari, meja belajar, dan poster kata-kata motivasi.
\end{abstract}

Kata Kunci : Minat, Membaca., Rumah Baca, Masyarakat

\begin{abstract}
The aim of this community service is to increase the interest and culture of reading by pioneering community learning houses in Gang H. Hasan Kota Pontianak. The method used in this service is a field survey and Tinakan. The field survey was conducted by visiting the location, coordinating with the residents who would be involved in the pioneering activities of the reading house. The action taken was the procurement of tools and materials to make facilities to support the reading house and the implementation of the program. The activities carried out in pioneering the Community Reading House in Pontianak's Gang H. Hasan can be seen that the implementation was in accordance with the indicators to be achieved. It can be seen from the related facilities to become facilities and infrastructure in the reading house that can be fulfilled in the form of cabinets, study desks, and posters of motivational words.
\end{abstract}

Keywords: Interest, Reading, Home Reading, Society 


\section{PENDAHULUAN}

Pengaruh riil yang tampak pada kehidupan masyarakat di Indonesia ialah masih banyak masyarakat menengah kebawah yang lebih mengutamakan kebutuhan pokok, seperti makanan, pakaian, dan rumah, daripada mengutamakan buku atau pendidikan. Berbeda jauh dengan masyarakat menengah keatas yang lebih mengutamakan membeli sesuatu yang dapat meningkatkan gaya hidup/prestise mereka, seperti alat komunikasi HP, dan alat trasportasi seperti mobil, bahkan dapat membeli jabatan atau kedudukan, ketimbang buku. Kedua golongan masyarakat tersebut juga lebih senang menghabiskan waktu luang dengan mengunjungi tempat-tempat hiburan atau menonton televisi yang sifatnya hiburan, bukan edukasi. Kedua situasi ini disebabkan karena belum adanya budaya membaca di kalangan masyarakat. Oleh karena itu, pemerintah, praktisi pendidikan, LSM dan masyarakat telah dan sedang melakukan berbagai upaya yang diharapkan mampu meningkatkan apresiasi masyarakat untuk membaca.

Dalam masyarakat pada umumnya, setiap hari puluhan koran, majalah, bahkan buku-buku selalu diproduksi dan dipasarkan. Di dalam semua jenis media itu akan dijumpai informasi mengenai pengetahuan, berita, lapangan pekerjaan, iklan, dan sebagainya, yang mau tak mau harus diserap oleh masyarakat modern tersebut baik modern secara waktu maupun secara kultural. Membaca, sudah seharusnya menjadi kebutuhan hidup sehari-hari masyarakat. Menurut Santoso (2008) mengemukan membaca merupakan suatu kegiatan seseorang untuk memperoleh informasi atau pesan dalam bentuk bahasa tulis, lambang-lambang atau simbol-simbol. Untuk dapat menangkap informasi dengan cepat seseorang harus membaca dengan serius apa yang dibacanya.

Keseriusan akan sulit diciptakan apabila seseorang tidak mempunyai minat baca terhadap apa yang dibacanya. Menurut Meckel (1983) dalam Rachman (1996) minat baca adalah kegiatan membaca yang dilakukan atas mauan-inisiatif pribadi seseorang tanpa pengaruh dari pihak lain atau luar. Senada dengan hal tersebut, (Gage, Ed. 1983) Rachman (1996) berpendapat bahwa kegiatan membaca yang dilakukan seseorang sebagai hasil atau akibat pengaruh langsung dan disengaja melalui serangkaian tindakan dan program yang terpola terutama 
kegiatan program belajar-mengajar di sekolah. Perwujudan dalam minat baca yang dikemukakan Meckel itu tidak dapat dilihat sebagai perilaku yang berbeda, tetapi dilihat sebagai sesuatu yang mewujud pada perilaku yang sama, yaitu yang mewujud pada kegiatan membaca. Menurut Harris dan Libe (1960) menyatakan bahwa minat dapat dilihat atau dinilai dari :

1. Wujud pernyataan atau pengakuan seseorang terhadap objek-objek tertentu

2. Wujud perilaku seseorang dalam melakukan sesuatu (membaca)

Menurut Henry (Gage, Ed., 1963: 992) bahwa pada dasarnya dalam memahami minat baca ada beberapa masalah pokok yaitu : 1) Buku atau bacaan yang dibaca; 2) Alasan yang mendorong seseorang memilih atau membaca buku atau bahan bacaan tertentu; Sedangkan menurut Rachman (1996: 10) ada beberapa masalah pokok dalam minat baca, yaitu jumlah buku atau bahan bacaan yang telah dibaca seseorang dan buku atau bahan bacaan yang disenangi seseorang.

Kegiatan membaca akan terlaksana apabila ada minat dari orang yang bersangkutan. Minat mempunyai daya dorong yang kuat dalam terwujudnya suatu kegiatan. Minat bisa muncul karena dua faktor yaitu internel dan eksternal. Faktor internal artinya kemauan yang datang dari diri seseorang, sedangkan eksternal merupakan kemauan yang datang dari luar diri seseorang. Faktor internal yang dimaksud dapat berupa keinginan dan rasa yang menggerakkan seseorang untuk melakukan tindakan seperti datang ke tempat sarana belajar, mencari buku baca, menulis, mencatat dan sebagainya. Sedangkan eksternal kemauan yang dimaksud semua datang dari luar diri seseorang, seperti daya dukung sarana prasarana, serta sumber dan media belajar.

Rendahnya minat baca masyarakat menjadikan kebiasaan membaca yang rendah, dan kebiasaan membaca yang rendah ini menjadikan kemampuan membaca rendah. Kondisi demikian yang sedang terjadi pada masyarakat sekarang ini. Selama ini selalu ada pernyataan bahwa masyarakat Indonesia belum mempunyai budaya baca atau dengan kata lain minat baca rendah. Pernyataan tersebut merupakan kenyataan yang benar adanya dengan bukti bahwa dari sekian banyak masyarakat yang ada di Indonesia, melalui perbandingan ketersedian 
perpustakaan, hanya sebagian kecil atau tidak banyak masyarakat yang mengunjungi perpustakaan. Mereka yang berkunjung ke perpustakaan rata-rata mereka yang sedang mengerjakan tugas makalah dari guru/dosennya, terlebih untuk tugas akhir berupa skripsi, tesis, ataupun disertasi bahkan sekedar rekiasi studi.

Fenomena di atas, dimana masyarakat pada kawasan bantaran Sungai Kapuas masih rendah minat bacanya, maka hendaknya minat baca (kegemaran) harus terus ditumbuhkan di kalangan masyarakat, terlebih sejak masih kanakkanak. Salah satu terobosan baru yang patut ditiru dan diapresiasi adalah sebuah langkah konkret oleh Dosen Pendidikan Geografi dan Prodi Pendidikan PPKN IKIP PGRI Pontianak berupa program Pengabdian Kepada Masyarakat (PKM). Pengabdian Kepada Masyarakat yang dimaksud sebagai bentuk dalam menjalin mitra atau kerjasama IKIP PGRI Pontianak dengan masyarakat, dan lingkungan sekitar dengan basis ilmu pendidikan dan pengetahuan berdasarkan bidang yang dimiliki atau khususnya Pendidikan Geografi dan Pendidikan PPKN. Wujud dari kerjasama yang ingin dilakukan disini yakni mengaplikasikan ilmu pengetahuan yang dimiliki dosen Pendidikan Geografi dan Pendidikan PPKN kepada masyarakat khususnya Gang. H. Hasan untuk memberdayakan Rumah Warga (Bapak Efrizar dan Ibu Yulida) yang dirintis menjadi Taman Bacaan Masyarakat pada lingkungan tersebut di Kota Pontianak.

\section{METODE}

Metode pelaksanaan pemberdayaan masyarakat dalam merintis rumah baca Gang H. Hasan Kota Pontianak menggunakan Survey dan Tindakan. Menurut Iskandar (2008: 66) Penelitian survey adalah penelitian yang dilakukan melalui pengamatan langsung terhadap suatu gejala atau pengumulan informasi dari populasi besar maupun kecil, tetapi data yang dipelajari merupakan data populasi tersebut. Kegunaan lainnya dari penelitian survey adalah untuk mengadakan evaluasi. Disini yang menjadi pertanyaan pokok adalah: sampai seberapa jauh tujuan yang digariskan pada awal program tercapai atau mempunyai 
tanda-tanda akan tercapai (Singarimbun \& Effendi, 1989: 5). Metode tersebut akan dijelaskan pada bagian berikut ini:

\section{A. Survei Lapangan}

Dalam pelaksanaan survei, seluruh tim melaksanakan tahapan berikut ini :

1. Survei lapangan yaitu secara langsung melihat kondisi lokasi yang akan dijadikan sasaran pelaksanaan program pengabdian di Jln. Adi Sucipto, Gang H. Hasan Kota Pontianak.

2. Koordinasi dengan pihak rumah baca, Ketua RT, dan warga setempat untuk menganalisis mengenai kebutuhan yang diperlukan untuk lokasi pengabdian yang mencakup sarana dan prasarana pendukung pengembangan rumah baca bagi kepentingan warga serta menentukan waktu pelaksanaan program agar secara cepat dapat terealisasi sesuai rancangan.

3. Melakukan analisis terhadap kesesuaian dan kelayakan program yang dilakukan dengan kebutuhan masyarakat setempat.

\section{B. Tindakan}

Berdasarkan hasil survei, maka tim membuat perencanaan sebagai dasar melaksanakan kegiatan merintis rumah baca tersebut. Perencanaan yang dimaksud meliputi :

\section{Pengadaan Alat dan Bahan}

Adapun alat dan bahan yang dibutuhkan untuk merintis Rumah Baca Masyarakat Gang H. Hasan Kota Pontianak sebagai berikut:

1. Alat

2. Bahan

3. Sumber/alat Baca

4. Cara Kerja
Palu, Gergaji, Paku, Meteran, Alat Penghalus Permukaan Kayu (Katam), Engsel Pintu lemari, Paku, Lem Kayu, Cat Kayu, dan Pernis.

Kayu Balok, Triplek.

Buku-buku, Poster, dan Banner Motivasi membaca .

Merancang dan Membuat Lemari Buku, dan Meja Belajar, Bingkai Bener dan Papan Nama 
Rumah Baca Masyarakat.

\section{Pelaksanaan Program}

Pelaksanaan yang akan dilakukan seluruh Tim dalam kegiatan ini dapat berupa:

a. Aksi nyata dalam merintis Rumah Baca masyarakat di lingkungan Gang. H. Hasan Kota Pontianak dengan menyediakan dan memberikan fasilitas alat dan bahan seperti yang disebutkan di bagian 1, serta membuat kelengkapan membaca seperti lemari, meja belajar dan bingkai poster motivasi menuntut ilmu.

b. Menyediakan dan memberikan fasilitas bacaan seperti buku, poster dan banner berkenaan dengan pembelajaran yang dapat meningkatkan minat dan budaya membaca baca masyarakat di Gang H. Hasan Kota Pontianak.

c. Pelaksanaan program pengabdian yang dilakukan bersama tim dosen dan mahasiswa serta warga setempat dalam upaya mewujudkan kelengkapan pendukung di rumah baca. Aktivitas yang dilakukan tim bersama warga antara lain: 1) membuat almari buku bantuan warga dan tim pengabdian, 2) membuat meja dan bangku guna kebutuhan belajar bagi anak-anak setempat, 3) pemasangan banner motivasi arti pentingnya menuntut ilmu melalui kebiasaan membaca, 4) membuat papan tulis untuk mempermudah menyampaikan materi bagi para pengajar dan lain sebagainya.

\section{HASIL DAN PEMBAHASAN}

Pelaksanaan kegiatan pengabdian kepada masyarakat yang bertema melaksanakan kegiatan "Merintis Rumah Baca" tersebut berawal dari satu diantara tim melakukan identifikasi dan bahkan mengetahui situasi dilingkungan yang menjadi sasaran PKM. Hasil proses identifikasi diperoleh informasi/data bahwasannya terdapat rumah warga yang sudah lama dibangun menjadi tempat belajar mengaji anak-anak. Berangkat dari situasi tersebut dibangunlah sebuah tempat sederhana yang berada dibantaran Sungai Kapuas sebagai lokasi belajar 
oleh salah seorang warga setempat. Pembangunan lokasi awalnya dilakukan dengan modal pribadi oleh inisiator (Efrizar \& Yulida) yang bertempat tinggal disekitar bantaran sungai karena melihat semangat anak-anak dalam upaya menuntut ilmu. Seiring berjalannya waktu banyak warga sekitar yang tergugah untuk memberikan sumbangan guna membantu pembangunan lokasi/tempat belajar bagi anak-anak setempat. Meskipun lokasi/tempatnya tidak begitu luas, tetapi minimal dapat memberikan manfaat yang luar biasa bagi warga setempat khususnya dalam memperoleh pengetahuan baik dibidang pendidikan maupun non pendidikan. Seperti halnya sebagai tempat belajar mengaji, membaca, menulis, bahkan dijadikan sebagai tempat pertemuan dan pelatihan bagi ibu-ibu yang memiliki keterampilan menjahit dan merajut.

Berdasarkan hasil pengamatan dan penggalian informasi yang dilakukan oleh tim (dosen dan mahasiswa) mengenai kondisi lokasi/tempat belajar, maka diputuskan untuk melakukan program pengabdian masyarakat di Jln. Adi Sucipto tepatnya Gang H. Hasan Kota Pontianak. Penentuan lokasi untuk pelaksanaan program mengacu pada beberapa indikator antara lain: 1) asas kebermanfaatan bagi masyarakat, 2) faktor jarak relatif dekat dengan kampus yang dapat dilakukan pemantauan terhadap perkembangan program, 3) faktor pendanaan program, 4) mitra program yang dapat bekerja sama secara maksimal, 5) memiliki potensi untuk dikembangkan. Tujuan pelaksanaan program pengabdian selain melaksanakan tri dharma perguruan tinggi harapannya juga dapat memberikan manfaat bagi masyarakat dalam upaya peningkatan indek pembangunan manusia sesuai visi dan misi pemerintah daerah Kalimantan Barat.

Bentuk program pengabdian yang dilakukan tim bukan hanya sekedar memberikan bantuan pendanaan dalam upaya pengembangan lokasi/tempat belajar, tetapi turut serta berpartisipasi aktif merealisasikan segala bentuk kebutuhan pendukung yang belum terwujud. Seperti halnya ikut serta membuat almari/rak buku hasil bantuan dari berbagai pihak yang mendukung terealisasinya lokasi/tempat belajar. Selain itu, membuat meja, bangku, papan tulis, tempat alas kaki, penyusunan banner motivasi sebagai sarana pendukung kegiatan belajar bagi masyarakat. Pembuatan sarana yang dimaksud tidak hanya dilakukan dalam 
jangka waktu satu kali, melainkan beberapa kali kegiatan dengan keterlibatan tim dengan warga setempat sebagai bentuk dukungan terhadap realisasi lokasi/tempat belajar. Tujuan yang ingin dicapai oleh inisiator dan tim tidak lain untuk menumbuhkan kesadaran terhadap masyarakat setempat maupun sekitar wilayah lokasi program mengenai arti penting rintisan lokasi/tempat belajar bagi generasi muda agar tidak terpengaruh pada hal-hal yang sifatnya negatif. Lebih lanjut mengenai partisipasi tim dan warga dalam merealisasikan program dapat dilihat pada gambar 1 berikut:

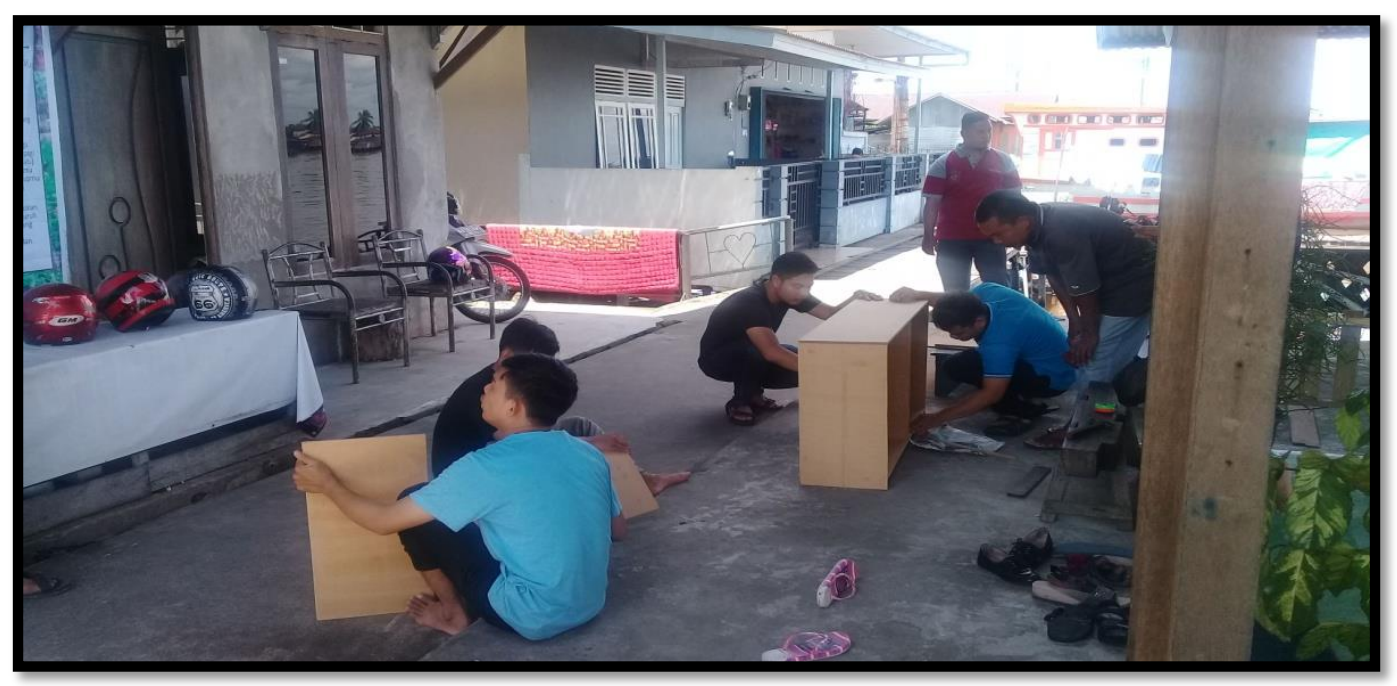

Gambar 1. Pembuatan Almari Buku

Sampai saat sekarang rintisan lokasi/tempat belajar sudah terdapat penjadwalan aktivitas masyarakat mulai Pendidikan Anak Usia Dini (PAUD), pelatihan keterampilan, dan Taman Pendidikan Alqur'an (TPA) yang terbagi menjadi 3 sesi yang berbeda (pagi, siang dan malam). Peserta PAUD yang dilaksanakan pada pagi sudah mencapai 20 anak yang berasal dari lingkungan sekitar wilayah Bangka Belitung Laut. Untuk pelatihan keterampilan menjahit sasarannya tidak lain para ibu-ibu rumah tangga yang notabene mengisi waktu luang bahkan bisa dijadikan profesi dalam usaha membantu ekonomi keluarga. Sedangkan TPA dengan sasaran anak-anak usia dini dalam upaya meberikan pembekalan ilmu agama yang dapat dijadikan sebagai salah satu bekal hidup mereka kedepannya. Pada dasarnya ketiga aktivitas yang dilakukan dilokasi/tempat belajar faktanya mampu memberikan dampak bagi warga 
setempat, meskipun dirasa belum semua lapisan masyarakat dapat merasakan secara maksimal. Untuk itu, kerjasama tim, inisiator, dan masyarakat setempat melalui program pengabdian menyepakati lokasi/tempat belajar dirumuskan menjadi "Rumah Baca" bagi warga setempat tidak hanya anak-anak usia dini atau sekolah, melainkan bagi seluruh masyarakat sesuai tingkat kebutuhannya.

Pemberian nama rumah baca dimaksudkan untuk menarik minat masyarakat sekitar untuk mengunjungi dan bahkan membaca buku-buku yang telah disediakan sesuai keinginan. Melalui membaca sudah barang tentu masyarakat minimal memperoleh informasi dan bahkan dapat mengembangkan potensi yang dimiliki, sehingga bisa dijadikan modal untuk memperoleh penghasilan/income kebutuhan keluarga. Sebagai contoh yang dilakukan inisiator disekitar lokasi rumah baca, mampu membuat keramba untuk budidaya ikan air tawar. Hasil budidaya ikan selanjutnya dipasarkan disekitar wilayah Bangka Belitung Laut dengan harga relatif terjangkau bagi masyarakat lapisan bawah. Pendapatan yang diperoleh inisiator sebagian untuk pemenuhan kebutuhan seharihari dan sisanya diberikan ke rumah baca guna pemenuhan kebutuhan pendukung dalam usaha pengembangan.

Rancangan pengembangan inisiator dan tim kedepannya dengan memperluas area rumah baca melalui pembangunan fisik ke atas (lantai 2). Hal ini dilakukan karena kapasitas daya tampung untuk kegiatan belajar dan membaca dirasa sudah tidak memenuhi, sehingga perlu dilakukan perluasan. Saat ini kegiatan belajar dan membaca baik untuk anak-anak maupun masyarakat masih menjadi satu dilantai 1. Meskipun kondisi tersebut sudah disiasati dengan penjadwalan dari pagi sampai malam, tetapi masih belum bisa mengatasi permasalahan tersebut. Harapannya kedepan untuk fasilitas rumah baca antara tempat belajar dan membaca akan terpisah, sehingga tidak mengganggu kelancaran kegiatan belajar maupun pelatihan keterampilan bagi kelompok yang sudah berjalan sampai sekarang. Berdasarkan informasi dan evaluasi program pengabdian pada tahap pertama oleh tim dan inisiator diperoleh kesepakatan bahwasannya akan dilanjutkan program berikutnya untuk perluasan bangunan guna pengembangan rumah baca. 
Inisiator dan tim yakin dengan kegiatan perluasan akan mampu memberikan stimulus positif dalam upaya peningkatan kualitas sumberdaya manusia kedepan dengan keterlibatan masyarakat setempat. Langkah lanjutan yang perlu ditempuh tim dan inisiator adalah legalitas rumah baca melalui komunikasi dengan pemerintah setempat dengan cara pemaparan kondisi yang ada serta kebermanfaatannya terhadap masyarakat khususnya peningkatan budaya membaca. Hal ini tidak bisa diabaikan karena dampak yang akan ditimbulkan cukup besar ketika legalitas rumah baca tidak diakui keberadaannya oleh pemerintah.

\section{SIMPULAN}

Berdasarkan kegiatan yang telah dilaksanakan dalam merintis Rumah Baca Masyarakat di Gang H. Hasan kota Pontianak dapat dilihat bahwa pelaksanaan telah sesuai dengan indikator yang ingin dicapai. Terlihat dari fasilitas - fasilitas yang terkait untuk menjadi sarana dan prasarana di rumah baca dapat terpenuhi berupa lemari, meja belajar, dan poster kata-kata motivasi. Menyediakan dan memberikan fasilitas bacaan seperti buku, poster dan benner yang berkenaan dengan pembelajaran yang dapat meningkatkan minat dan budaya membaca baca masyarakat di Gang H. Hasan Kota Pontianak.

\section{UCAPAN TERIMA KASIH}

Terimakasih kami ucapkan kepada Rektor IKIP PGRI Pontianak, Kepala Lembaga Penelitian dan Pengabdian Kepada Masyarakat, Inisiator (Efrizar dan Yulida) yang telah membantu dalam merintis rumah baca masyarakat di jalan $\mathrm{H}$. Hasan Kota Pontianak.

\section{DAFTAR PUSTAKA}

Abdul Rachman.dkk. 1996. Minat Baca Murid SD Di Jawa Timur. Pusat Pembinaan dan pengembangan Bahasa Depdikbud.

Harris, Chester W \& Marie R Libe. 1960. Encyclopedia of Education Research A Proyect of the American Education Research Association, Edisi Ketiga New York: The Mac Millan Company 
Hari Santoso. 2008. Membangun Minat Baca Anak Usia Dini Melalui Penyediaan Buku Bergambar. [Online]. Tersedia http://digilib.um.ac.id/images/stories/pustakawan/pdfhasan/Membangun\%2 0minat\%20baca\%20anak\%20usia\%20dini\%20melalui\%20penyediaan\%20b uku\%20bergambar.pdf [20 Februari 2018].

Iskandar, 2008. Metodologi Penelitian Pendidikan dan Sosial (Kuantitatif dan Kualitatif. Jakarta: Gaung Persada Press (GP Press).

Singarimbun Masri \& Effendi Sofian, 1989. Metode Penelitian Survai. Jakarta: LP3ES. 